\title{
The Assessment of Financial Leasing Risk in Grid Corporation
}

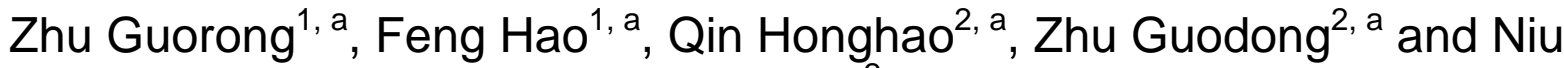 Dongxiao ${ }^{2, \text { a }}$}

${ }^{1}$ Electric Power Research Institute, Zhejiang Electric Power Grid Corporation, Shang Cheng District, Hangzhou 310000, China

${ }^{2}$ School of Economics and Management, North China Electric Power University, Hui Long Guan,Chang Ping District, Beijing 102206, China

azhugdbj@163.com

Keywords: grid corporate; financial leasing; risk assessment; strategy

\begin{abstract}
There are certain risks while financial leasing address the needs of funds in power grid construction. It is possible to provide some references to the management of grid corporate financial leasing risks by assessing the risk of financial leasing. This paper analyzes the risk of financial leasing existing in grid companies, and constructs the index system of assessment of risks, and establishes the model of assessment of financial leasing risks in grid corporate by fuzzy comprehensive evaluation method. Finally, this paper verifies the validity of the model through an example, and proposes some strategies to decreasing financial leasing risks in grid corporate.
\end{abstract}

\section{Introduction}

In order to meet the huge demand of power grid construction, it has become a real problem of grid corporate in production and operation and financial management that how to raise a large amount of low-cost, small risk of construction funds. Currently, the funds of power grid project construction mainly rely on state funds and loans, but financing costs are included in their Balance Sheet, which resulting in higher ratio of debt asset and pressure of repaying capital with interest. This has restricted the development of China's power grid. And in the construction of power grid projects, financing costs are not included in the grid corporate's debt asset by financial leasing, and the ratio of debt asset does not change, so, financial leasing has become an ideal financing mode to increase capital and relief financing debt in power companies.

Financial leasing is a new type of financing which was introduced from abroad in the 80's. In financial leasing of grid projects, due to the late start, the laws and regulations and market credit are inadequate, and grid projects related to the huge amount of investment funds, the long lease period and the uncertain factor within the payback period, which makes large risk of financial leasing in grid enterprises and affects financial leasing application in power project construction seriously. So, it is that how to assess the risk of financial leasing in grid construction effectively and take measures to reduce or avoid the risk, has become an urgent problem in power grid enterprises financial leasing.

As a typical financial services, the management of financial leasing risk has caused a lot of attention. There are many scholars having been studied it. Schmit analyzed the credit risk of retail leasing, and estimated the loss of density function by analyzing tens of thousands of pieces of leasing products of financial institutions using sample statistical methods, and noted the important role of guaranteed mortgage in reducing the credit risk [1]. Yan, An presented a model to incorporate different theories on the substitutability and complementarity between leases and debt, and investigated the variation in the substitutability between leases and debt [2]. Yang Jian, Han Lixin analyzed the current situation and problems of China's ship financial leasing industry, and proposed the advantages and risks of ship financial leasing industry [3]. Chen Dong cai researched the theory and application of financial leasing in power engineering projects from the micro-level, and built a theoretical framework of analyzing grid project finance leases based on the lessor [4]. Jin Chao mao and Zhang Yu bo identified the financial leasing risk of grid project combining with 
the actual situation of power grid projects and put forward some preventive measures using expert investigation method, fault tree analysis and curtain scene method [5]. Chen Bao zhen analyzed the measurement method of power project finance lease rental based on the industry background and their own characteristics, and proposed principles of the rental calculation, and built a rental income econometric model of grid project based on the revenue of lessor [6].

Overall, the existing researches of financial leasing risk in power grid corporate is relatively lack, and they mostly focused on qualitative analysis and theoretical introduction of existing problems. Many scholars researched financial leasing risk from the perspective of the lessor generally, rarely involving the risk of lessee, and it is difficult to provide effective help about existing problems in power companies. Therefore, this paper establishes risk assessment model based on the lessee from the perspective of power companies, using fuzzy comprehensive evaluation method, and verifies the effectiveness by analyzing examples, and proposes strategy to decrease risk of financial leasing in grid companies.

\section{The assessment of Grid corporate financial leasing risk}

\section{Construction of Risk Assessment System}

There are many financial leasing risks of grid enterprises, and only identify the risks scientifically and properly, can we assess the risks correctly.

(1) Technical risks. Due to the length of power grid project lease and widespread influence, the stability and maturity of network equipment technology is very important. If the device is not stable operation during the lease, the costs of the equipment maintenance will be greatly increased for lessee, resulting in a great impact to the operating income of lessee. With the technological development and the use of the leased asset consumption, it has a negative impact on the ability to pay the rent that technology updates and follow-up services are not in place.

(2) Financial risks. Since there are time value of money and value of risks, rent and payment of leased assets will affect the financial situation of the power grid companies. If benefits can be generated with the leased asset, it can reduce the risk of financial leasing effectively. In addition, the uncertain of residual value of leased assets may have some risks to grid companies. In financial leasing contract, the asset's residual value cannot be completely accurate with the actual value when the lease expires, which is estimated in advance and affected by the length of the lease, the way of rent payment and the impact of future technology development and market competition.

(3) The risk of the lease contract. It is uncertain whether the ownership of the leased asset transferred when the lease expires. Although deal with the finance lease assets as its own assets based on the accounting principle, it need to be made clear in the contract of how to deal with the unexpected costs, such as maintenance costs, property insurance, the cost of asset improvement.

(4) Market environmental risks. Because of the legal system of current financial leasing is not perfect, there are many inconsistencies between law and policy, and the lessor and the lessee's rights are not protected. And tax and tariff adjustment will bring some risks to grid companies, and affect the operating results and financial condition. During the lease, power companies will face risks of changes of interest rates and inflation.

Based on the above analysis, we establish risk assessment system of financial leasing from the viewpoint of the lessee of power companies, as shown in Table 1.

\section{The establishment of financial leasing Risk Assessment Model}

According to the table 1, we evaluate the risk of financial leasing applying the fuzzy comprehensive evaluation method, from the viewpoint of the lessee of grid business perspective, and content and steps are as follows:

(1) Determine the set of factors to be evaluated.

The set of factors $\mathrm{U}$ is divided into three levels:

The first level: $\mathrm{U}=\left[u_{1}, u_{2}, u_{3}, u_{4}\right]$;

The second level: $\mathrm{U}_{1}=\left[u_{11}, u_{12}, u_{13}\right], \mathrm{U}_{2}=\left[u_{21}, u_{22}\right], \mathrm{U}_{3}=\left[u_{31}, u_{32}\right], \mathrm{U}_{4}=\left[u_{41}, u_{42}\right]$;

The third level: $\mathrm{U}_{41}=\left[u_{411}, u_{412}\right], \mathrm{U}_{42}=\left[u_{421}, u_{422}, u_{423}\right]$. 
(2) Determine the comment set of object to be evaluated.

Hypothesis $\mathrm{V}=\left[v_{1}, v_{2}, \cdots, v_{n}\right]$. It is a collection of comment set that consists of various evaluation results. Where: $v_{i}$ represents the $\mathrm{i}$-th evaluation results, $\mathrm{i}=1,2, \ldots \mathrm{n}$, and $\mathrm{n}$ is the total number of the evaluation results, which are divided into 3 to 5 levels usually.

Between the assessment indicators of grid corporate finance leases risk, we can change qualitative indicators into quantitative indicators by the method of experts scoring, considering the many qualitative factors. And process discretely and describe the property of risks by applying the theory of fuzzy mathematics. Respectively, lower risk, low risk, moderate risk, high risk, higher risk are the five levels of risk.

Therefore, the risk classification set $\mathrm{V}=\left[v_{1}, v_{2}, v_{3}, v_{4}, v_{5}\right], v_{1}, v_{2}, v_{3}, v_{4}, v_{5}$ represent lower risk, low risk, moderate risk, high risk and higher risk. Hypothesis $\mathrm{V}=[2,4,6,8,10]$, where 2,4,6,8,10 represent lower risk, low risk, moderate risk, high risk, higher risk.

Table 1 . The evaluation system of financial leasing risk

\begin{tabular}{|c|c|c|}
\hline The first level indicator & The second level indicator & The third level indicator \\
\hline \multirow{3}{*}{ Technical risk $\left(u_{1}\right)$} & Technical renewal risk $\left(u_{11}\right)$ & \\
\hline & Technical stability risk $\left(u_{12}\right)$ & \\
\hline & $\begin{array}{l}\text { High cost of maintenance and } \\
\text { technology use }\left(u_{13}\right)\end{array}$ & \\
\hline \multirow{2}{*}{ Financial risk $\left(u_{2}\right)$} & $\begin{array}{l}\text { Uncertainty risk of residual value } \\
\text { of leased assets }\left(u_{21}\right)\end{array}$ & \\
\hline & $\begin{array}{l}\text { Rent and operating cash flow does } \\
\text { not match }\left(u_{22}\right)\end{array}$ & \\
\hline \multirow{2}{*}{$\begin{array}{l}\text { The risk of the lease } \\
\text { contract }\left(u_{3}\right)\end{array}$} & $\begin{array}{l}\text { Uncertainty risk of lease term } \\
\text { asset ownership }\left(u_{31}\right)\end{array}$ & \\
\hline & $\begin{array}{llll}\text { Unexpected } & \text { cost } & \text { risk } & \text { during } \\
\text { lease }\left(u_{32}\right) & & & \\
\end{array}$ & \\
\hline \multirow{5}{*}{$\begin{array}{l}\text { Market environmental risk } \\
\left(u_{4}\right)\end{array}$} & \multirow{2}{*}{ Financial risk $\left(u_{41}\right)$} & Interest rate risk $\left(u_{411}\right)$ \\
\hline & & Inflation risk $\left(u_{412}\right)$ \\
\hline & \multirow{3}{*}{ Policy legal risk $\left(u_{42}\right)$} & $\begin{array}{l}\text { The risk of financial leasing } \\
\text { policy and regulations }\left(u_{421}\right)\end{array}$ \\
\hline & & $\begin{array}{l}\text { The risk of tax rate adjustment } \\
\left(u_{422}\right)\end{array}$ \\
\hline & & $\begin{array}{l}\text { The risk of Electricity price } \\
\text { adjustment }\left(u_{423}\right)\end{array}$ \\
\hline
\end{tabular}

(3) Single factor fuzzy evaluation and establish fuzzy relation matrix R.

After the configuration of the grade fuzzy subset, it has to be evaluated to quantify object individually from each factor $\mathrm{u}_{i}$, which is determined by the membership to be evaluated from the point of a single factor fuzzy subset of each grade, and then get fuzzy relationship matrix:

$$
\mathrm{R}=\left[\begin{array}{cccc}
r_{11} & r_{12} & \ldots & r_{1 n} \\
r_{21} & r_{22} & \ldots & r_{2 n} \\
\vdots & \vdots & \ddots & \vdots \\
r_{m 1} & r_{m 2} & \ldots & r_{m n}
\end{array}\right]
$$

Where $r_{i j}$ represents an evaluated object from the point of the rating factors $u_{i}$ fuzzy subset membership $v_{j}$. A performance evaluation object is a factor in terms of $u_{i}$ through fuzzy vector $r_{i}$ to portray, and $r_{i}$ called single-factor evaluation matrix, and it can be seen as a fuzzy relationship factor set between $U$ and $V$, which influence the reasonable relationship between the factors and evaluate objects.

In determining affiliation, score the evaluation issues on the basis of judgment grade by experts or professionals usually, then the results of statistical scoring can be found by the method of absolute value and subtraction.

$$
r_{i j}=\left\{\begin{array}{c}
1, \quad(i=j) \\
1-c \sum_{k=1}\left|x_{i k}-x_{j k}\right|, \quad(i \neq j)
\end{array}\right.
$$


Where c is chosen properly, the requirements $0 \leq r_{i j} \leq 1$.

(4) Determine the fuzzy evaluation index weight vector.

Deal with the feedback information of experts using statistical analysis methods to determine the value of each basic indicators $\mathrm{u}_{\mathrm{i}}$, and these indicators constitute evaluation factors set $\mathrm{U}$.

Determine the number of layers of index weight $\mathrm{A}$, using variation method and Delphi method, reflecting the importance of each factors, namely a set of data for each indicator $\mathrm{a}_{1}, \mathrm{a}_{2}, \ldots, \mathrm{a}_{\mathrm{n}}$, Hypothesis $\mathrm{A}=\left(\mathrm{a}_{1}, \mathrm{a}_{2}, \cdots, \mathrm{a}_{\mathrm{m}}\right)$ and it is the weight distribution fuzzy vectors, where $a_{i}$ is the weight of the i-th factor, requiring $a_{i} \geq 0, \sum a_{i}=1$, denoted as

$$
\begin{gathered}
\bar{a}=\frac{1}{n} \sum_{i=1}^{n} a_{i} \\
\sigma_{j}=\left(\frac{1}{n-1} \sum_{i=1}^{n}\left(a_{i}-\bar{a}\right)^{2}\right)^{1 / 2}
\end{gathered}
$$

So that,

$$
c_{j}=\frac{\sigma_{j}}{|\bar{a}|}
$$

It is the coefficient of variation of an array of $\mathrm{a}_{1}, \mathrm{a}_{2}, \ldots, \mathrm{a}_{\mathrm{n}}$. And weights

$$
\omega_{j}=\frac{c_{j}}{\sum_{i=1}^{k} c_{i}}
$$

(5) Comprehensive evaluation (Synthesis of fuzzy comprehensive evaluation result vector).

Calculate fuzzy comprehensive evaluation results of vector B by synthesizing A and R using a suitable operator, namely:

$$
\mathrm{A}^{\circ} \mathrm{R}=\left(a_{1}, a_{2}, \cdots, a_{q}\right)\left[\begin{array}{cccc}
r_{11} & r_{12} & \cdots & r_{1 m} \\
r_{21} & r_{22} & \cdots & r_{21} \\
\vdots & \vdots & \ddots & \vdots \\
r_{q 1} & r_{q 1} & \cdots & r_{q m}
\end{array}\right]=\left(b_{1}, b_{2}, \cdots, b_{m}\right)=B
$$

Where $b_{j}$ is calculated based on $A$ and $j$-th column of $R$, and it is said to be judged by the degree of membership of the fuzzy subset of the $\mathrm{V}_{\mathrm{j}}$ level.

(6) Analyze the fuzzy comprehensive evaluation results.

The results of Fuzzy comprehensive evaluation is subject to the membership of each grade fuzzy sets. Generally, it is a fuzzy vector, rather than a point value. So it can provide richer information than other methods. Comparison of the plurality of evaluation objects and sorting, need further processing, in other word, calculate comprehensive score for each evaluation object, and sort by size. Evaluation results will be converted to an integrated value B.

\section{Case Analysis}

This paper selects a leasing project of a provincial power grid company as a case, employing 7 experts to quantify the risk assessment.

(1) Index weights

According to the weight data given by experts, and using equation (2) (3) (4) (5), we calculate:

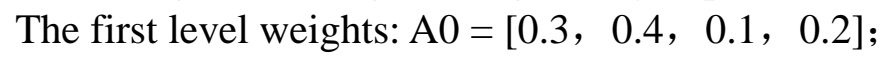

The second level weights: $\mathrm{A} 1=[0.3,0.3,0.4], \mathrm{A} 2=[0.4,0.6], \mathrm{A} 3=[0.3,0.7], \mathrm{A} 4=[0.6,0.4]$;

The third level weights: $A 41=[0.4,0.6], \mathrm{A} 42=\left[\begin{array}{ll}0.2,0.5,0.3\end{array}\right]$.

Calculated indicators weights of the end level:

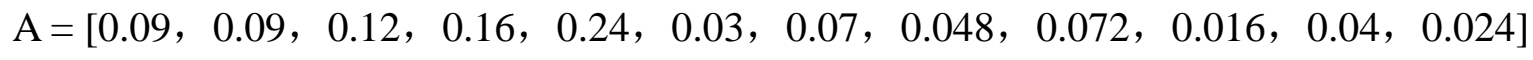

(2) Fuzzy comprehensive evaluation

The fuzzy evaluation matrix given by experts is as follows: 


$$
\mathrm{R}=\left[\begin{array}{ccccc}
0.5 & 0.4 & 0 & 0.1 & 0 \\
0.3 & 0.3 & 0.4 & 0 & 0 \\
0.2 & 0.8 & 0 & 0 & 0 \\
0.8 & 0.1 & 0 & 0.1 & 0 \\
0.2 & 0.4 & 0.4 & 0 & 0 \\
0.1 & 0.6 & 0.3 & 0 & 0 \\
0.5 & 0.5 & 0 & 0 & 0 \\
0.7 & 0.3 & 0 & 0 & 0 \\
0.2 & 0.5 & 0.2 & 0.1 & 0 \\
0.4 & 0.6 & 0 & 0 & 0 \\
0.7 & 0.2 & 0 & 0.1 & 0 \\
0.4 & 0 & 0.6 & 0 & 0
\end{array}\right]
$$

With model $\mathrm{M}(\bullet,+)$ (matrix operation) calculated:

$\mathrm{B}=\mathrm{A} \cdot \mathrm{R}=\left[\begin{array}{lllll}0.4020 & 0.3920 & 0.1698 & 0.0362 & 0\end{array}\right]$ 。

And then calculate the integrated score:

$\mathrm{U}=\mathrm{B} \cdot \mathrm{V}=3.6804$

\section{(3) Result Analysis}

The comprehensive evaluation value of this leasing project risks is $U=3.6804$, ranging between lower risk and low risk, which indicates that this leasing project overall is good, but there are still some risks that need to guard against carefully. From the index weight of the calculation example, the financial risk and technical risk is the biggest risk to this financing leases project, and play a decisive role in overall lease project risk. The lease contract risk and market environmental risk is small due to the little possible of occurrence, so they have little impact on the leasing project.

\section{Strategies of awareness the financial leasing risk}

(1) Power grid enterprises should select outstanding technical services lessor, and requires lessors continue to provide technical services and renovation of assets, mitigating risks and impacts of technological obsolescence and the unstable performance of products and services.

(2) Combine rent and cash flow by applying scenario analysis, so that maintain long-term stable source of rent and the consistent of the rent paid, controlling the financial leasing risk effectively.

(3) Establish a risk equalization mechanism between the lessee and the lessor, and reduce the risk of uncertainty of the residual value of leased assets.

(4) In the choice of rent payment, it should coordinate the rent with the cash flow generated by the business, reducing volatility shortage of the rent paid.

(5) Select experienced technical and legal experts to participate to the negotiation of financial leasing contract, in order to avoid the risk of accidental damage caused by asset.

\section{Conclusions}

For risks of financial leasing in the grid enterprise, this paper chooses a scientific and rational risk assessment system, using the theory of fuzzy comprehensive evaluation, combining with the grid business reality, and establishes an assessment model of financial leasing risk based on the lessee. Then this paper analysis an example and proposes the coping strategies, controlling the leasing project risk of grid companies effectively, and improving the management capabilities of finance lease risk in power grid enterprises.

\section{References}

[1] Schmit M. Credit risk in the leasing industry[J]. Journal of banking \& finance, 2004, 28(4): 811-833.

[2] Yan A. Leasing and debt financing: substitutes or complements?[J]. Journal of Financial and 
Quantitative Analysis, 2006, 41(03): 709-731.

[3] Han Lixin. Reach on risks and countermeasures of Chinese ship financial leasing faced with the global economic crisis [J]. SCIENCE AND MANAGEMENT, 2010, 31(6): 182-186.

[4] Chen Dondcai. Theory and applications of power project finance leases [D]. North China Electric Power University (Beijing), 2008.

[5] Jin Chaomao, Zhang Yubo. The management of risk of Grid project finance leasing [J]. Technology Economics and Management Research 2008 (6): 98-99.

[6] Chen Baozhen. Research the rental model of grid project finance lease based on the perspective of the lessor[D]. North China Electric Power University (Beijing), 2011.

[7] Rong Shaohua. Risk management strategies of finance lease based on the perspective of lessee

[J]. Traffic Accounting, 2009 (7): 33-35 